\title{
Growth and characterization of reactive DC magnetron sputtered aluminum titanate thin films
}

\author{
A. Suresh ${ }^{1,2, a *}$, S. Uthanna $a^{1, b}$ \\ ${ }^{1}$ Department of Physics, Sri Venkateswara University, Tirupati - 517 502, India \\ ${ }^{2}$ Center for NanoScience and Engineering, Indian Institute of Science, Bangalore - 560 012, India \\ E-mail address: aemail: suresh181083@gmail.com, bemail:uthanna@rediffmail.com
}

Keywords: $\mathrm{Al}_{2} \mathrm{TiO}_{5}$ films, Magnetron sputtering, Annealing, Structure, Optical properties

ABSTRACT. Aluminum titanate $\left(\mathrm{Al}_{2} \mathrm{TiO}_{5}\right)$ films were deposited on to unheated p-silicon and quartz substrates by reactive DC magnetron sputtering of $\mathrm{Al}_{67} \mathrm{Ti}_{33}$ target at an oxygen flow rate of 8 $\mathrm{sccm}$ and at sputter pressure of $2 \times 10^{-3}$ mbar. The as-deposited films were annealed in oxygen ambient at $600^{\circ} \mathrm{C}$. The as-deposited and annealed films were characterized for chemical composition core level binding energies, crystallographic structure and optical properties. The asdeposited films were amorphous in nature while those annealed in oxygen were of polycrystalline with orthorhombic structure. Atomic force micrographs confirmed the fine grain growth of the films and the size of the grain increased in annealed films. The films showed optical transmittance of above $85 \%$ in the visible region. The optical band gap of the films decreased from $4.58 \mathrm{eV}$ to 4.50 $\mathrm{eV}$.

\section{INTRODUCTION}

Metal insulator metal (MIM) capacitors are important components in the integrated circuits. In order to down scaling the components it is required high density MIM capacitors for analog, radio frequency and mixed signal applications [1]. The traditional dielectrics silicon dioxide $\left(\mathrm{SiO}_{2}\right)$ and silicon nitride $\left(\mathrm{Si}_{3} \mathrm{~N}_{4}\right)$ have low dielectric constants, low capacitance and high leakage currents restricted to down scaling the devices [2]. For high performance of MIM capacitors, various high dielectric thin films such as $\mathrm{Al}_{2} \mathrm{O}_{3}, \mathrm{HfO}_{2}, \mathrm{ZrO}_{2}, \mathrm{TiO}_{2}$ and $\mathrm{Ta}_{2} \mathrm{O}_{5}$ have been investigated in order to achieve high capacitance density with reduced leakage current density [3-7]. Among these materials, aluminum titanate $\left(\mathrm{Al}_{2} \mathrm{TiO}_{5}\right)$ is a high-k dielectric with good radio frequency performance. Thin films of $\mathrm{Al}_{2} \mathrm{TiO}_{5}$ have been deposited by various techniques such as thermal oxidation of $\mathrm{Al} / \mathrm{Ti}$ bilayer formed by vacuum evaporation [8], reactive sputtering [9], Low pressure chemical vapor deposition [10,11], nanoparticle achieved by sol-gel process $[12,13]$. The thermally oxidized $\mathrm{AlTiO}_{\mathrm{x}}$ thin film MIM capacitors exhibited capacitance density of about $1 \mu \mathrm{F} / \mathrm{cm}^{2}$ and high leakage current density of about $10^{-4} \mathrm{~A} / \mathrm{cm}^{2}$ due to deficiency of oxygen in the films [8]. Sputter deposited $\mathrm{Al}_{2} \mathrm{TiO}_{5}$ films are used as semitransparent silicon thin film solar cell useful for building integrated photovoltaic system [9], Low pressure chemical vapor deposition films formed were amorphous and their refractive index decreased from 1.92 to 1.78 and the dielectric constant decreased with increase of substrate temperature from $350^{\circ} \mathrm{C}$ to $500^{\circ} \mathrm{C}[10,11]$ respectively. Further annealing of films as temperature to $800^{\circ} \mathrm{C}$ resulted the enhanced dielectric properties [11]. In this investigation, an attempt is made in the deposited of $\mathrm{Al}_{2} \mathrm{TiO}_{5}$ thin films by $\mathrm{DC}$ reactive magnetron sputtering and annealed in oxygen atmosphere at temperature of $600^{\circ} \mathrm{C}$, and studies their structural and optical properties.

\section{EXPERIMENTAL TECHNIQUES}

Thin films of $\mathrm{Al}_{2} \mathrm{TiO}_{5}$ were deposited onto p- type silicon(100) and quartz substrates by DC reactive magnetron sputtering system using composite target of $\mathrm{Al}_{67} \mathrm{Ti}_{33}$ (99.9\% purity) of $75 \mathrm{~mm}$ diameter. The silicon and quartz substrates were thoroughly cleaned with organic solvents and dried before loading in to the sputter chamber. The sputter chamber was pumped down to $1 \times 10^{-5} \mathrm{mbar}$ by employing diffusion pump and rotary pump combination. Before deposition of each film the target was presputtered for 20 minutes in pure argon ambient in order to remove any contamination on the 
target surface. Oxygen and argon (99.999\% purity) gases were used as reactive and sputter gases respectively. These gases were admitted in to the sputter chamber through individual mass flow controllers (Aalborg model No. GFC17). The target to substrate distance maintained was $80 \mathrm{~mm}$. The films were deposited in the sputter up configuration. The experimental films were deposited on the substrates held at room temperature with oxygen flow rate of $8 \mathrm{sccm}$ (oxygen partial pressure was $3 \times 10^{-4}$ mbar) and at a sputter pressure of $2 \times 10^{-3}$ mbar. The DC power density of $2.26 \mathrm{~W} / \mathrm{cm}^{2}$ was supplied to the sputter target for deposition of the films. The sputter deposition parameters maintained during the growth of the films are given in table 1. The as-deposited films were also annealed in oxygen ambient for one hour at $600^{\circ} \mathrm{C}$.

Table 1 Deposition conditions maintained for the growth of $\mathrm{Al}_{2} \mathrm{TiO}_{5}$ thin films

$\begin{array}{ll}\text { Sputter target } & : \mathrm{Al}_{67} \mathrm{Ti}_{33} \mathrm{composite} \text { target } \\ \text { Target to substrate distance } & : 80 \mathrm{~mm} \\ \text { Ultimate pressure } & : 1 \times 10^{-5} \mathrm{mbar} \\ \text { Sputter pressure } & : 2 \times 10^{-3} \mathrm{mbar} \\ \text { Sputter power } & : 8 \mathrm{sccm} / \mathrm{cm}^{2} \\ \text { Oxygen flow rate } & : \text { Room temperature }\left(30^{\circ} \mathrm{C}\right) \\ \text { Substrate temperature } & \end{array}$

Thickness of as-deposited films was determined with Ellipsometer (J.A. Woollam Model M2000U). Core level binding energies and chemical composition of the as-deposited and annealed films were determined by using X-ray photoelectron spectroscope (Axis, Ultra DLD) with aluminum as X-ray source. The crystallographic structure of the films was analyzed with X-ray diffractometer (Rigaku, Smart Lab) with glancing angle of $0.5^{\circ}$ using copper $\mathrm{K}_{\alpha}$ radiation of 0.15406 $\mathrm{nm}$. The surface morphology and roughness of the films was determined with atomic force microscope (Bruker Model Dimension ICON) with tapping mode. The optical transmittance of the filmsdeposited on quartz substrates were recorded in the range $200-1000 \mathrm{~nm}$ (Shimadzu Model UV 3600). Refractive index of the films was determined with Ellipsometer.

\section{RESULTS AND DISCUSSION}

Thickness of the as-deposited films determined by ellipsometer was $95 \mathrm{~nm}$. X-ray photoelectron spectroscopic studies were performed on the as-deposited and annealed films in order to determine the core level binding energies and chemical composition. Figure 1 shows the X-ray photoelectron spectrum of as-deposited films. The spectrum contained the characteristic core level binding energy peaks of aluminum, titanium and oxygen indicated the formation of aluminum titanium oxide films. The core level binding energy seen at about $73 \mathrm{eV}$ related to $\mathrm{Al} 2 \mathrm{p}$ of aluminum, $460 \mathrm{eV}$ correspond to $\mathrm{Ti} 2 \mathrm{p}$ of titanium and $530 \mathrm{eV}$ connected to $\mathrm{O} 1 \mathrm{~s}$ of oxygen. Narrow scan X-ray photoelectron spectra of as-deposited and the films

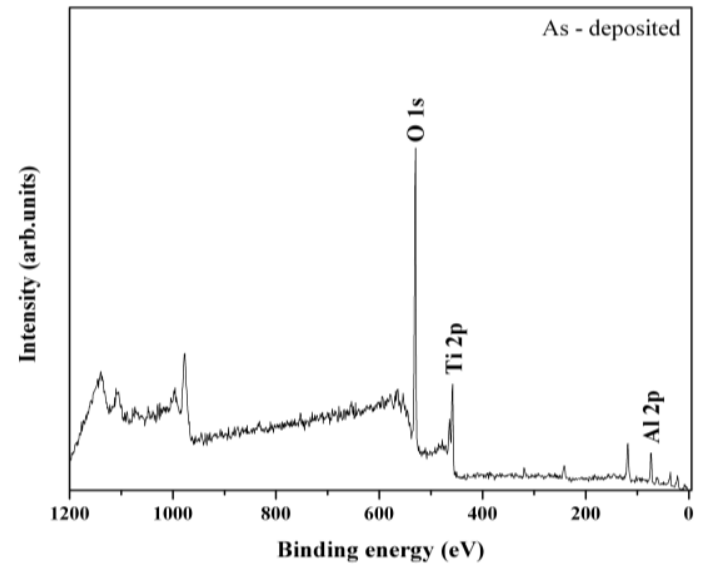

Figure 1. X-ray photoelectron spectrum of as-deposited aluminum titanium oxide films 
annealed at $600^{\circ} \mathrm{C}$ are shown in figure 2. It is seen from the figure 2 (a) that the core level binding energy of $\mathrm{Al} 2 \mathrm{p}$ was $74.2 \mathrm{eV}$ in the as-deposited films. In the as-deposited films the core level binding energy of Ti $2 p$ split in to two that is $458.7 \mathrm{eV}$ for Ti $2 p_{3 / 2}$ and $464.3 \mathrm{eV}$ for Ti $2 \mathrm{p}_{1 / 2}$ due to spin-orbit splitting and with separation in the energy of $5.6 \mathrm{eV}$ (Figure 2 (b)). The core level binding energy of $\mathrm{O} 1 \mathrm{~s}$ was $530.5 \mathrm{eV}$ (Figure 2(c)). In the case of annealed films the core level binding energies shifted towards lower energy side that is $73.2 \mathrm{eV}$ for $\mathrm{Al} 2 \mathrm{p}, 457.5 \mathrm{eV}$ and $463.0 \mathrm{eV}$ for Ti $2 p_{3 / 2}$ and Ti $2 p_{1 / 2}$ and $529.7 \mathrm{eV}$ for $\mathrm{O} 1 \mathrm{~s}$. The shift in the core level binding energies clearly indicated that the annealing leads to fill the oxygen vacancies in the aluminum titanium oxide films. It is to be noted that in as-deposited films the core level binding energy separation between Ti $2 p_{3 / 2}$ and $\mathrm{Ti} 2 \mathrm{p}_{1 / 2} \mathrm{Of} 5.6 \mathrm{eV}$ confirmed the presence of $\mathrm{Ti}^{4+}$ in oxidation state [14]. The core level binding energy of $74.2 \mathrm{eV}$ of $\mathrm{Al} 2 \mathrm{p}$ suggested the occurrence of $\mathrm{Al}^{3+}$ in oxidation state. It is to be noted that the core levels binding energies $\mathrm{Ti} 2 \mathrm{p}_{3 / 2}$ and Ti $2 \mathrm{p}_{1 / 2}$ were $458.2 \mathrm{eV}$ and $464.0 \mathrm{eV}$ respectively in DC magnetron sputtered $\mathrm{TiO}_{2}$ films $[15,16]$, while in DC magnetron sputtered $\left(\mathrm{Ta}_{2} \mathrm{O}_{5}\right)_{0.85}\left(\mathrm{TiO}_{2}\right)_{0.15}$ films the binding energies were $458.7 \mathrm{eV}$ and $464.3 \mathrm{eV}$ [17]. The chemical composition of the asdeposited films was determined from the core level binding energy peak area and the sensitivity factors of the constituent elements of aluminum, titanium and oxygen [18]. Chemical composition of the as-deposited film was aluminum $=25.9$ at. $\%$, titanium $=12.7$ at. $\%$, oxygen $=61.4$ at. $\%$. These results indicated that the as-deposited films were of stoichiometric $\mathrm{Al}_{2} \mathrm{TiO}_{5}$.
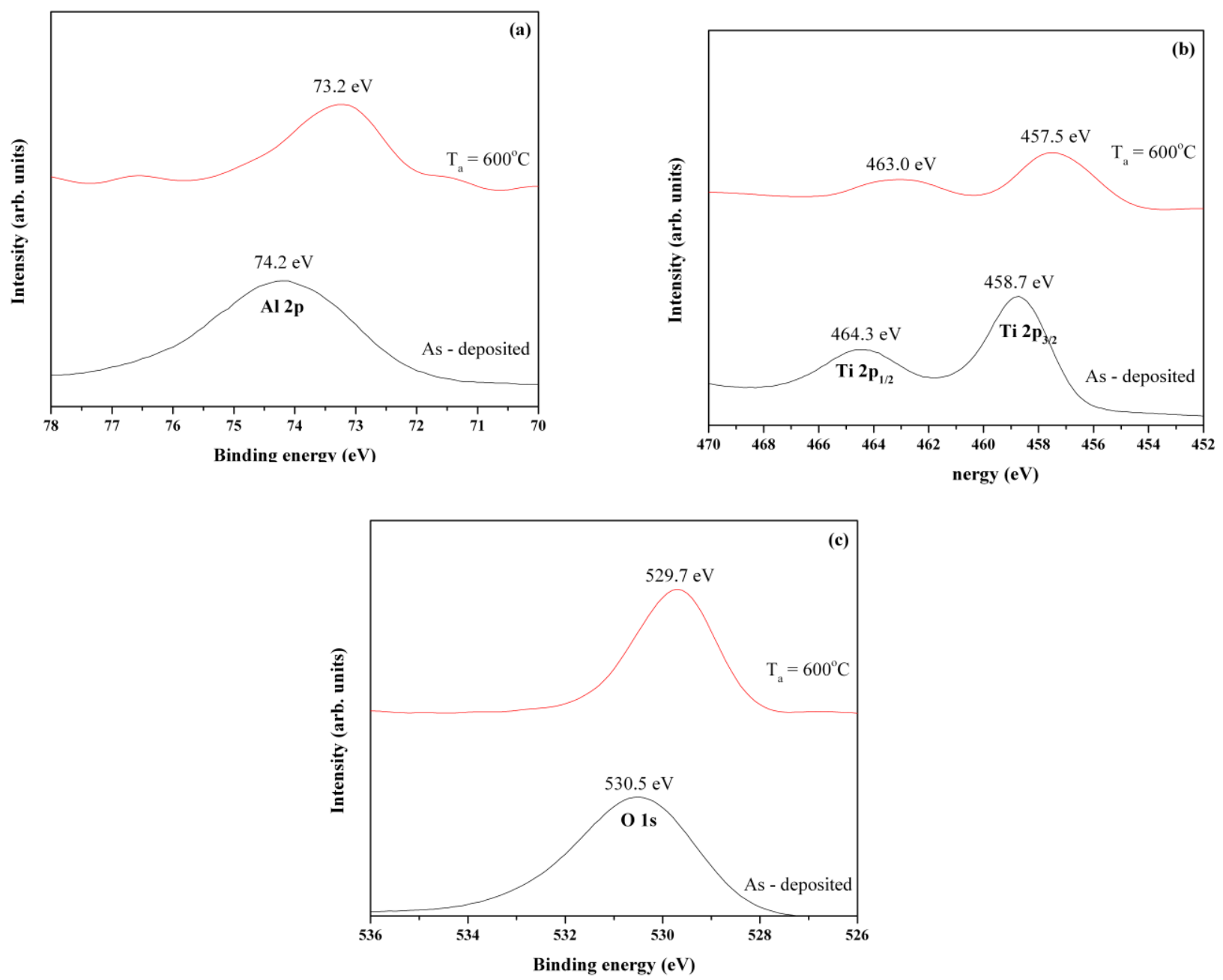

Figure 2. Narrow scan X-ray photoelectron spectra of $\mathrm{Al}_{2} \mathrm{TiO}_{5}$ films: (a) $\mathrm{Al} 2 \mathrm{p}$, (b) $\mathrm{Ti} 2 \mathrm{p}$ and (c) $\mathrm{O} 1 \mathrm{~s}$

X-ray diffraction profiles of as-deposited and the films annealed at $600^{\circ} \mathrm{C}$ are shown in figure 3 . It is seen from the diffraction patterns that the as-deposited $\mathrm{Al}_{2} \mathrm{TiO}_{5}$ films were of $\mathrm{X}$-ray 
amorphous. When the films annealed at $600^{\circ} \mathrm{C}$ the diffraction profiles exhibited two peaks at $2 \theta=$ $50.7^{\circ}$ and $55.3^{\circ}$ related to the (200) and (220) reflections of $\mathrm{Al}_{2} \mathrm{TiO}_{5}$ [19]. It confirmed that the grown films were of $\mathrm{Al}_{2} \mathrm{TiO}_{5}$. The crystallite size (D) of the films was evaluated from the full width at half maximum intensity $(\beta)$ of the diffraction peak using Debye-Scherrer's relation

$$
\mathrm{D}=\mathrm{k} \lambda / \beta \cos \theta
$$

was about $5 \mathrm{~nm}$ in annealed films. It revealed that the small sized crystallites were embedded in the amorphous matrix of $\mathrm{Al}_{2} \mathrm{TiO}_{5}$.

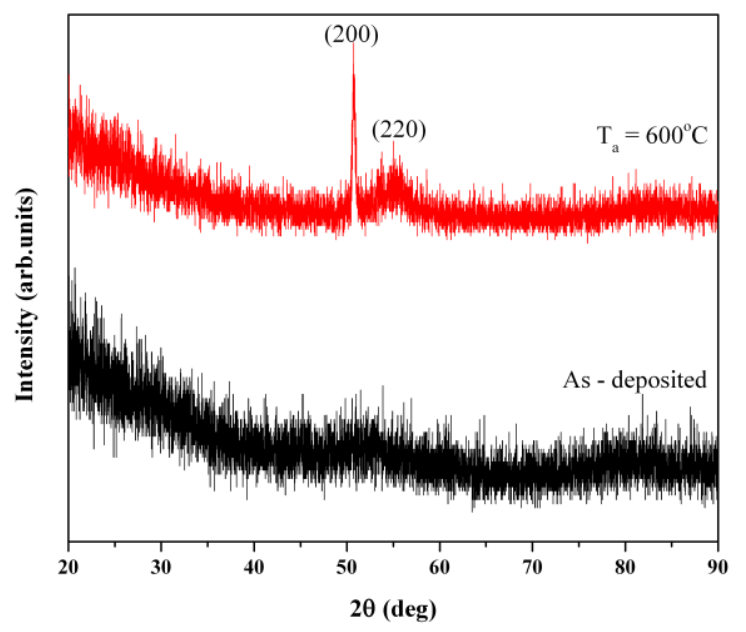

Figure 3. X-ray diffraction patterns of as-deposited and annealed $\mathrm{Al}_{2} \mathrm{TiO}_{5}$ films.

Figure 4 shows the atomic force micrographs of as-deposited and annealed $\mathrm{Al}_{2} \mathrm{TiO}_{5}$ films. The micrographs of the as-deposited film showed smooth surface indicated the homogenous and uniform surface. Size of the grains was about $20 \mathrm{~nm}$. There was no much variation in the surface morphology of the annealed films. The root mean square roughness of the films increased from 1.76 $\mathrm{nm}$ to $1.83 \mathrm{~nm}$ in as-deposited and annealed films. The increase in the surface roughness of the annealed films may be due to larger size grain growth. Such an increase in the size of the grains was also noticed in RF magnetron sputtered $\mathrm{TiO}_{2}$ films [20].
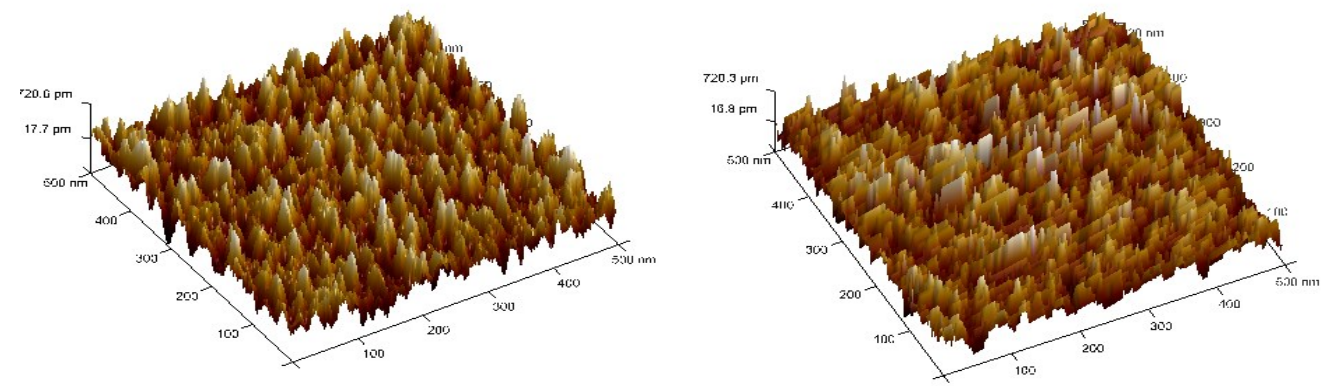

Figure. 4 Atomic force micrographs of as-deposited and annealed $\mathrm{Al}_{2} \mathrm{TiO}_{5}$ films.

Optical transmittance of the as-deposited and the annealed $\mathrm{Al}_{2} \mathrm{TiO}_{5}$ films formed on quartz substrates was recorded in the wavelength range $200-1000 \mathrm{~nm}$. Figure 5 shows the optical transmittance spectra of as-deposited and annealed $\mathrm{Al}_{2} \mathrm{TiO}_{5}$ films. The optical transmittance of asdeposited film was $92 \%$ (wavelength of $400 \mathrm{~nm}$ ) and it decreased to $88 \%$ in annealed films. The optical transmittance of about $80 \%$ was noticed in low pressure chemical vapor deposited and 
sputter deposited AlTiO films [9-11]. Fundamental absorption edge shifted to higher wavelength side with annealing temperature. The reduction in the transmittance in the annealed films may be due to increase in the surface scattering which related to the surface roughness [21]. Optical absorption coefficient $(\alpha)$ of the films was calculated from optical transmittance (T) using the relation,

$$
\alpha=-(1 / t) \ln T
$$

wheret is the film thickness. Optical band gap $\left(E_{g}\right)$ of the films was determined for the optical transmittance data by assuming the direct transition of electrons takes place from the top of the valance band to the bottom of the conduction band fitting to the Tauc's relation [22]

$$
(\alpha h v)=A\left(h v-E_{g}\right)^{1 / 2}
$$

where $\mathrm{A}$ is the absorption edge width parameter. By extrapolating the linear portion of the $(\alpha \mathrm{h} v)^{2}$ versus photon energy (hv) to the absorption coefficient to zero resulted the optical band gap. Figure 6 shows the plots of $(\alpha \mathrm{h} v)^{2}$ versus photon energy of as-deposited and annealed $\mathrm{Al}_{2} \mathrm{TiO}_{5}$ films. The optical band gap of the as-deposited $\mathrm{Al}_{2} \mathrm{TiO}_{5}$ film was $4.58 \mathrm{eV}$. The films annealed at $600^{\circ} \mathrm{C}$ showed the optical band gap of $4.50 \mathrm{eV}$. Such a decrease in the optical band gap with annealing temperature was also noticed in pulsed lased deposited and sputter deposited $\mathrm{TiO}_{2}$ films $[7,15,23]$.

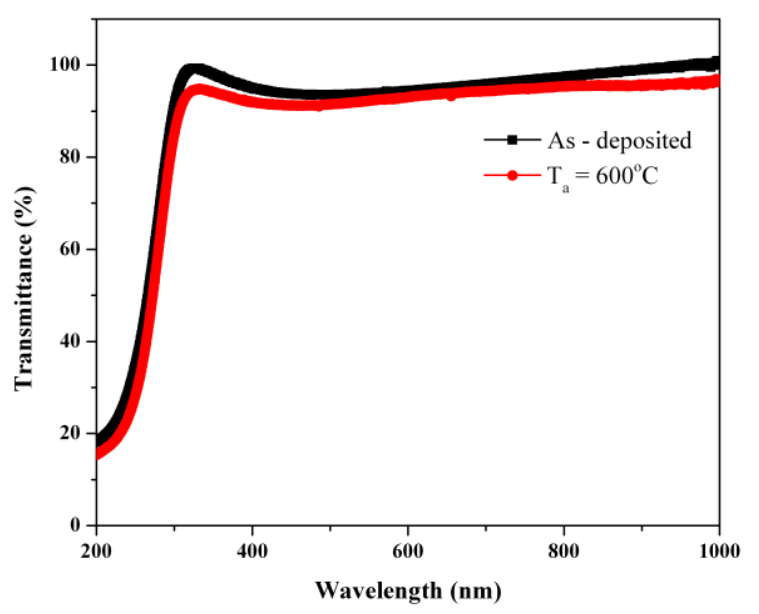

Figure 5 Optical transmittance spectra of as-deposited and annealed $\mathrm{Al}_{2} \mathrm{TiO}_{5}$ films

Refractive index of the $\mathrm{Al}_{2} \mathrm{TiO}_{5}$ films was determined with ellipsometric method. Wavelength dependent refractive index of the as-deposited and the $\mathrm{Al}_{2} \mathrm{TiO}_{5}$ films annealed at $600^{\circ} \mathrm{C}$ in figure 7 . In general, refractive index of the films decreased with increase of the wavelength. It is seen from the figure that the refractive index of as-deposited films decreased from 1.82 to1.71 with increase of wavelength from $400 \mathrm{~nm}$ to $1000 \mathrm{~nm}$ respectively. In the case of annealed $\mathrm{Al}_{2} \mathrm{TiO}_{5}$ films the refractive decreased from 1.77 to 1.66 with increase of wavelength from $400 \mathrm{~nm}$ to $1000 \mathrm{~nm}$. In the literature, it reported that the refractive index of $\mathrm{Al}_{2} \mathrm{O}_{3}$ was in the range $1.5-1.7[24,25]$ and the refractive index of $\mathrm{TiO}_{2}$ was in the range $2.0-2.7$ [26]. Refractive index of $\mathrm{Al}_{2} \mathrm{TiO}_{5}$ films at wavelength of $632.8 \mathrm{~nm}$ decreased from 1.70 to 1.68 . 


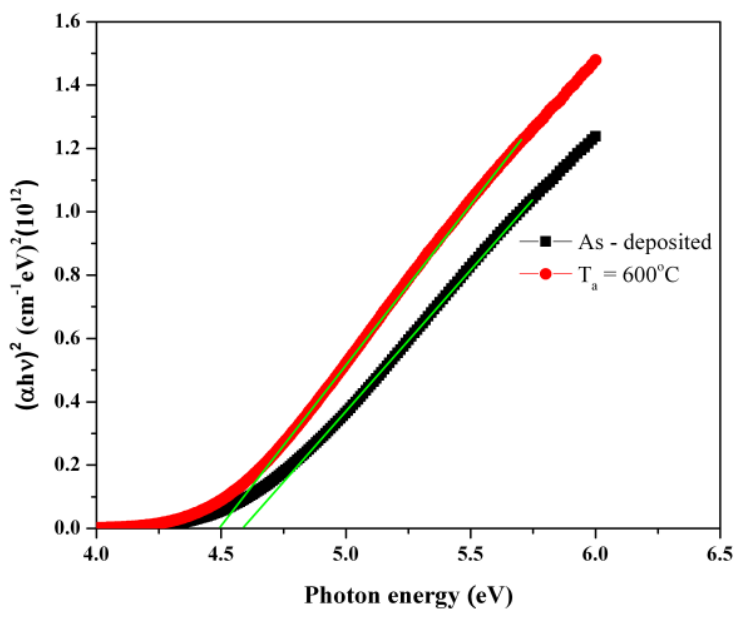

Figure 6. Plots of $(\alpha h v)^{2}$ versus photon energy of as-deposited and annealed $\mathrm{Al}_{2} \mathrm{TiO}_{5}$ films

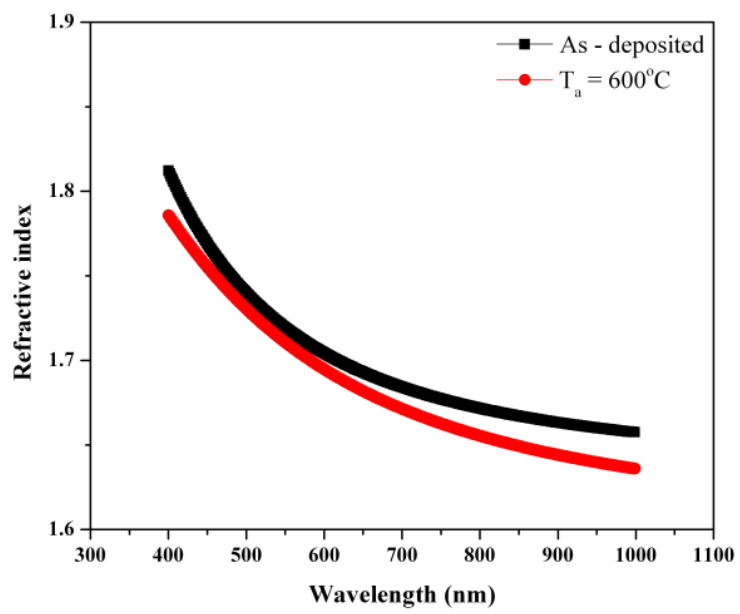

Figure 7. Wavelength dependent refractive index of as-deposited and annealed $\mathrm{Al}_{2} \mathrm{TiO}_{5}$ films

\section{CONCLUSIONS}

Thin films of $\mathrm{Al}_{2} \mathrm{TiO}_{5}$ were deposited on p- type silicon and quartz substrates held at room temperature by $\mathrm{DC}$ reactive sputtering of $\mathrm{Al}_{67} \mathrm{Ti}_{33}$ target at an oxygen flow rate of $8 \mathrm{sccm}$. The asdeposited films were annealed in oxygen ambient at temperature of $600^{\circ} \mathrm{C}$. The influence of annealing temperature on the structure and surface morphology and optical properties were investigated. The as-deposited films were $\mathrm{Al}_{2} \mathrm{TiO}_{5}$ and in amorphous phase. The films annealed at $600^{\circ} \mathrm{C}$ were of polycrystalline. X-ray photoelectron spectroscopic studies confirmed the existence of characteristic core level binding energies of $\mathrm{Al}_{2} \mathrm{TiO}_{5}$. The crystallite size of the annealed films was $5 \mathrm{~nm}$. Atomic force micrographs indicated the fine grain structure and the grown grains were uniformly distributed in the films. The optical transmittance of the films was more than $85 \%$ in the visible region in as-deposited and annealed films. Optical band gap of the films decreased from 4.58 $\mathrm{eV}$ to $4.50 \mathrm{eV}$ and refractive index decreased from 1.70 to 1.68 in the as-deposited and annealed $\mathrm{Al}_{2} \mathrm{TiO}_{5}$ films respectively.

\section{Acknowledgements}

The authors are thankful to National Nano Fabrication Centre (NNFC) and Micro and Nano Characterization Facility (MNCF) in the Centre for Nano Science and Engineering (CeNSE), Indian Institute of Science, Bangalore for extending the film characterization facilities to carry out the present work. 


\section{References}

[1] J. Yota, H. Shen and Ravi Ramanathan: Characterization of atomic layer deposited $\mathrm{HfO}_{2}, \mathrm{Al}_{2} \mathrm{O}_{3}$ and plasma enhanced chemical vapor deposited $\mathrm{Si}_{3} \mathrm{~N}_{4}$ as metal insulator metal capacitor dielectric for GaAs HBT technology, J. Vac. Sci. Technol. A31 (2013), 01A134.

[2] W. Liu, Handbook of III-V Heterojunction Bipolar Transistors, New York, John Wiley 1998

[3] W. G. Kim and S. W. Rhee, Microelectron. Eng. 86 (2009), 21539.

[4] K. J. Han, K. S. Kang, Y. Chen, K. H. Yoo and J. Kim: Effect of annealing temperature on the conduction mechanism for a sol-gel grown ZnO Schottky diode, J. Phys. D: Appl.Phys. 42 (2009), 125110.

[5] Z. Jiahui, C. Hudong, L. Honggang, L. Guiming, X. Wenjun, L.Qi, L.Simin, H. Zhiyi and L.Haiou: MIM capacitors with various $\mathrm{Al}_{2} \mathrm{O}_{3}$ thickness for GaAs RFIC application, J. Semicond. 36 (2015), 054004.

[6] P. Poulopoulos, S. Grammatikopoulos, D. Trachylis, G. Bissas, I. Dragatsikas, M. J. Velgakisand C. Politis: Growth and optical properties of nanocrystalline titania films for Optoelectronics and photovoltaics, J.Surf. Interface Mater.3 (2015), 52.

[7] K. A. Aadim, K. H. Abass and Q. M. Hadi: Effect of annealing temperature on the optical properties of $\mathrm{TiO}_{2}$ thin films prepared by pulse laser deposition, International Lett. Chem. Phys. Astronomy 56 (2015), 63.

[8] S. B. Chen, C. H. Lai, A. Chin, J. C. Hsieh and J. Liu: High density MIM capacitors using $\mathrm{Al}_{2} \mathrm{O}_{3}$ and $\mathrm{AlTiO}_{\mathrm{x}}$ dielectrics, IEEE Electron. Dev. Lett. 23 (2002), 183.

[9] S. Y. Lee, K. S. Bang and J. W. Lim: Sputter deposited AlTiO films for semitransparent silicon thin film solar cells, J. Electron. Mater.43 (2014), 3204.

[10] D. H. Kuo and C. N. Shueh: Properties of aluminum titanate films prepared by chemical vapor deposition under different aluminum butoxide inputs, Thin Solid Films 478 (2005), 109.

[11] D. H. Kuo and C. N. Shueh: Properties of CVD alumina-titania composite films grown at different $\mathrm{CO}_{2} / \mathrm{H}_{2}$ inputs, J. Non-Crystalline Solids 336 (2004), 120.

[12] S. Ananthakumar, M. Jayasankar and K. G. K. Warrier: Microstructural, mechanical and thermal characterization of sol-gel derived aluminum titanate-mullite ceramic composites, Acta Materialia 54 (2006), 2965.

[13] M. Jayasankar, S. Ananthakumar, P. Mukundan and K. G. K.Warrier: Low temperature synthesis of aluminum titanate by aqueous sol-gel route, Mater. Lett. 61 (2007), 790.

[14] R. Sanjines, H. Tang, H. Berger, F. Gozzo, G. Margaritondo and F. Levy: Electronic structure of anatase $\mathrm{TiO}_{2}$ oxide, J. Appl. Phys. 75 (1994), 2945.

[15] M. Chandra Sekhar, P. Kondaiah, G. Mohan Rao, S. V. Jagadeesh Chandra and S.Uthanna: Postdeposition annealing influenced structural and electrical properties of $\mathrm{Al} / \mathrm{TiO}_{2} / \mathrm{Si}$ gate capacitors, Superlattices Microelectronics 62 (2013), 68.

[16] Y. S. Liu, Y. H. Lin, Y. S. Wei and C. Y. Liu: Formation of carriers in titanium oxide thin films by substitution reactions, J. Appl. Phys. 111 (2012), 043103.

[17] M. Chandra Sekhar, N. Nanda Kumar Reddy, S. Victor Vedanayakan and M. Raja Reddy: Influence of post-deposition annealing on the structural and electrical properties of magnetron sputtered $\mathrm{Al} /\left(\mathrm{Ta}_{2} \mathrm{O}_{5}\right)_{0.85}\left(\mathrm{TiO}_{2}\right)_{0.15} / \mathrm{p}$-Si structure, J. Optoelectron. Adv. Mater.16 (2014), 1295.

[18] C. D. Wagner, L. E. Davis, M. V. Zeller, J. A. Taylor, R. H. Raymond and L. H. Gale: Empirical atomic sensitivity factors for quantitative analysis by electron spectroscopy for chemical analysis, Surf. Interface Anal. 3 (1981), 211. 
[19] JCPDS International Centre for Diffraction Data Card No.74-1759.

[20] N. Martin, C. Rousselot, D. Rondot, F. Palmino and R. Mercier: Microstructure modification of amorphous titanium oxide thin films during annealing treatment, Thin Solid Films 300 (1997), 113.

[21] D. Yoo, I. Kim,S. Kim, C. H. Hahn, C. Lee and S. Choi: Effects of annealing temperature and method on structural and optical properties of $\mathrm{TiO}_{2}$ films prepared by $\mathrm{RF}$ magnetron sputtering at room temperature, Appl. Surf. Sci. 253 (2007), 3888.

[22] J. Tauc, Amorphous and Liquid Semiconductors, Plenum Press, New York 1974.

[23] A. Akl, H. Kamal and K. A. Hady: Fabrication and characterization of sputtered titanium dioxide films, Appl. Surf. Sci. 252 (2006), 8651.

[24] V. A. C. Haanappel, J. B. Rem, H. D. Van Corbach, T. Fransen and P. J. Gellings: Properties of alumina films prepared by low pressure metal organic chemical vapor deposition, Surf. Coat.Technol. 72 (1995), 13.

[25] J. Saraie, K. Ono and S. Takeuchi: Effects of various atmospheres on the reduced pressure CVD of $\mathrm{Al}_{2} \mathrm{O}_{3}$ thin films at low temperatures, J. Electrochem. Soc. 136 (1989), 3139.

[26] K. Okimura, N. Maeda and A. Shibata: Characteristics of rutile $\mathrm{TiO}_{2}$ films prepared by RF magnetron sputtering at low temperatures, Thin Solid Films 281- 282 (1996), 427. 